\title{
A Thematic Review of the Studies on the Music Teacher Competencies in Turkey
}

\author{
Hatice Çeliktaş ${ }^{1}$, Doruk Engür ${ }^{2} \&$ Sezen Özeke ${ }^{2}$ \\ ${ }^{1}$ Freelance Researcher, Bursa, Turkey \\ ${ }^{2}$ Music Education Department, Bursa Uludag University, Bursa, Turkey \\ Correspondence: Hatice Çeliktaş, Bursa, Turkey.
}

Received: September 3, 2021

doi:10.5539/ies.v15n1p1

\author{
Accepted: October 19, $2021 \quad$ Online Published: December 23, 2021 \\ URL: https://doi.org/10.5539/ies.v15n1p1
}

\begin{abstract}
The first official works about the teacher competencies in Turkey were began in 1998 and many revisions made since then. In this framework, subject-specific competencies were prepared for some areas for primary education in 2008 and secondary education in 2011. This research aimed to review and analyze studies about music teacher competencies between 2008 and 2017 when music teacher competencies were in effect. For this purpose, the studies conducted during this period in Turkey were scanned, and the thematic content analysis was carried out within the framework of the method/design, sample group, data collection tools, aims, results, and recommendations. One of the research findings showed that the studies concerned were particularly related to the competency areas of planning and regulation, the theoretical-applied knowledge and skill, and professional development. Another finding pointed out that the vast majority of the studies employed a descriptive survey model. Last but not least, it was found that the samples of the studies were mostly constructed from pre-service teachers rather than in-service teachers. This current research suggests that further studies should give priority to choose in-service teachers as samples rather than pre-service teachers and also suggests more functional courses for both undergraduate program and in service training.
\end{abstract}

Keywords: music education, music teacher competencies, music teaching, thematic review

\section{Introduction}

Educating qualified students, improving educational activities in schools, and reaching the welfare levels of developed countries bring the issue of the need of qualified teachers. Today, this issue is tried to be achieved with the determination of teacher standards or teacher competencies in many countries (Seferoğlu, 2004) and many studies began to be realized worldwide in this field. Among them, while there are various studies which discussed the competencies of teachers, their attitudes and perceptions towards teaching (Bisschoff \& Grobler, 1998; Dörge, 2010; Dubrovina, Moskalenko, \& Zinchenko, 2020; Kowalczuk-Walêdziak, Korzeniecka-Bondar, Danilewicz, \& Lauwers, 2019; Menter, 2016; Organisation for Economic Cooperation and Development [OECD], 2009; Wilkerson \& Lang, 2007), many other researches were conducted in the literature by examining the music teaching competencies of preschool and primary school teachers, teacher candidates, and music teachers (Cho \& Cho, 2021; Davis, 2006; Denis \& Tucker, 2021; Hallam et al., 2009; Hash, 2010; Shin, 2019; Susic, 2018; Sungurtekin, 2016).

In the studies examining the music competencies of preschool teachers and candidates, it was seen that the music competencies of these teachers need to be improved (Elald1, Batd1, \& Sönmez-Ölger, 2020). Also, it is understood that preschool teachers and candidates feel inadequate especially in the application areas (Susic, 2018). Similarly, according to a research conducted by Begic, Begic, and Skojo (2017), teaching methods teachers in the universities stressed more practical training such as playing instruments and singing. And the study conducted by Hallam et al. (2009) concluded that primary school teacher candidates who play one or more instruments feel more confident about teaching music. As for the studies on the music competencies of primary school teachers, it is seen that teachers feel insecure about music teaching just like pre-school teachers, and they believe that music should be taught by music teachers (Hash, 2010). When the perceptions and attitudes of music teachers and candidates about their music teaching competencies are examined, it is seen that they feel competent and self-confident, unlike preschool and primary school teachers (Kaleli, 2020; Küçük, 2012; Yağcı \& Aksoy, 2015; Yokuş, 2014). Last but not least, in a study conducted by Denis and Tucker (2021), it is found that acquiring teaching competencies is more difficult than acquiring music competencies according to music teachers. As a result, it is seen that studies on 
competencies including preschool and primary school teachers' music teaching competencies are increasing field in the literature day by day.

While these topics have been discussed in the world widely, there were some developments in Turkey as well. When the educational structure has changed over the years in the Turkish Republic, socio-cultural structure and education needs have brought about the concrete steps to improve the quality of teacher education. Therefore, the concept of "teacher competencies" began to be discussed in all the levels of education. Within this framework, Ministry of National Education (MoNE) in Turkey carried out the first official studies in 1998 with the cooperation of Higher Education Council (HEC) and World Bank. As a result, MoNE determined teacher competencies and defined the competency as "knowledge, skills, attitudes and values that must be possessed to be able to perform a task effectively and efficiently" (Directorate General for Teacher Training and Development [DGTTD], 2017: II). According to this definition, MoNE listed teacher competencies under four headings: 1) competencies regarding subject matter and pedagogical subject matter, 2) competencies on the teaching-learning process, 3) monitoring, evaluation, and recording of students' learning, and 4) complementary professional competencies (DGTTD, 2017).

In 2006, with an agreement signed between the European Union Commission and the Turkish Government under the name of the Basic Education Support Program (Temel Eğitime Destek Programı), the Directorate General for Teacher Training and Education took the responsibilities for building teacher competencies to establish a common perspective for teacher education. Thus, six main competency areas were identified: 1) personal and professional values - professional development, 2) getting to know the student, 3) learning and teaching process, 4) monitoring and assessing the learning and development of students, 5) school, family and community relations, and 6) curriculum and subject content knowledge. As a result of this project, "General Competencies for Teaching Profession" was determined under these six main competency areas, associated with 31 competencies and 233 performance indicators. In addition to these competencies that came into force in 2006, "Subject Specific Competencies for Teaching Profession" were determined and put into effect in 14 different subject areas in 2008. Among these subject areas, "Music" had no exception (DGTTD, 2017).

Within the framework of these developments, Uçan (2006) evaluated the draft of the music teacher competencies and he emphasized the importance of this work. In addition, he asserted that subject-specific competencies for primary school music teachers became a very important development for the music teaching profession. These developments began to be strengthened with the studies in this field which emphasized the topics of competencies, attitudes, perceptions, and skills of music teachers (Birer \& Sonsel, 2013; Dursun, 2015; Güleryüz \& Demirci, 2016; Elald1, Batd1, \& Sönmez-Ölger, 2020; Küçük, 2012; Talşık, 2016; Temiz, 2016; Yağc1 \& Aksoy, 2015; Yokuş, 2014).

Within the scope of Music Teacher Competencies, main competency areas were defined under six headings: 1) planning and regulation, 2) theoretical-applied knowledge and skills, 3) music culture, 4) monitoring and evaluation, 5) school-family-society and interdisciplinary cooperation, 6) professional development. In addition, a total of 32 competencies under these competence areas were determined (DGTTD, 2008). Music Teacher Competencies are given in Figure 1. 

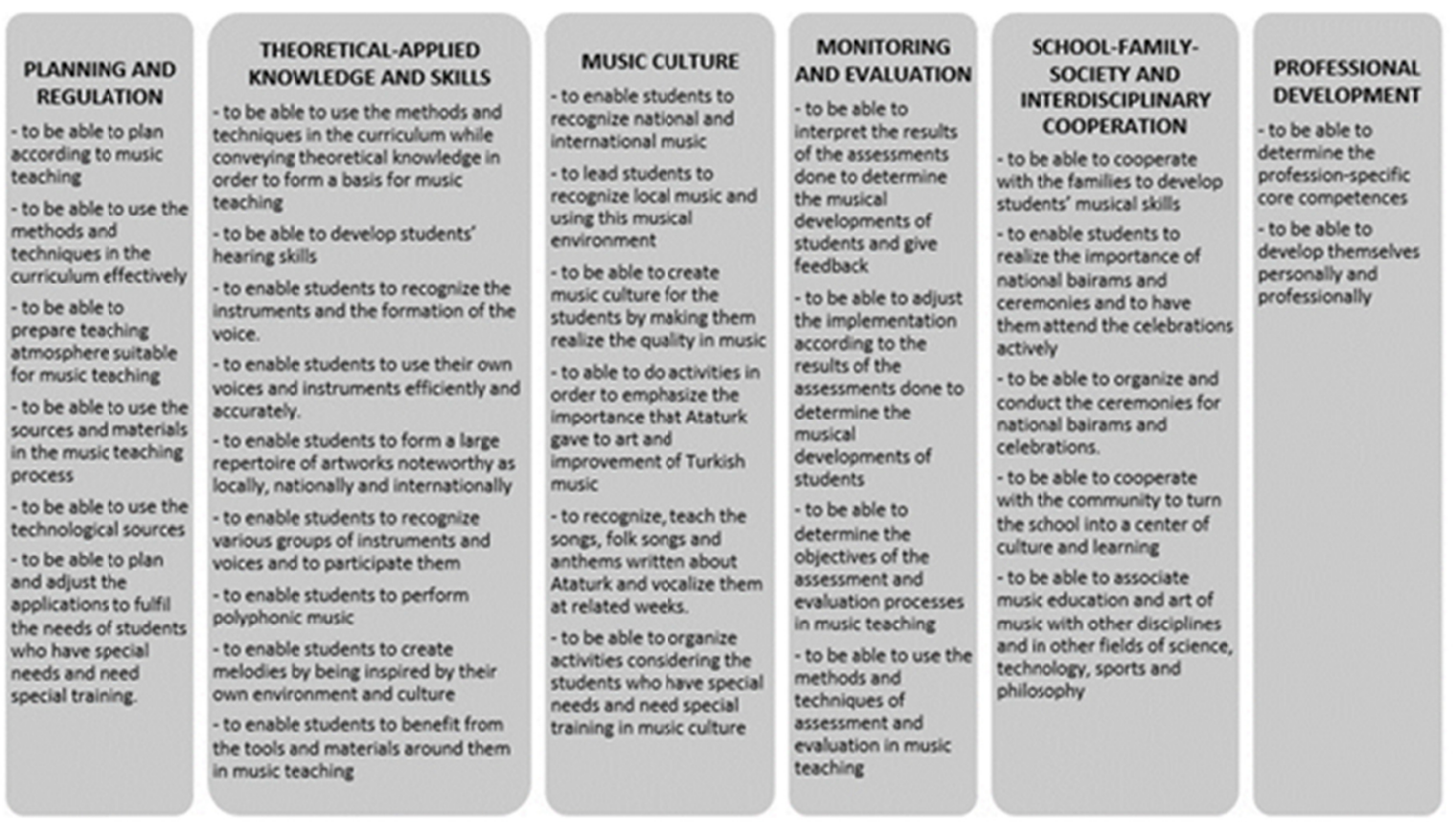

Figure 1. Music Teacher Competencies which were in effect between 2008 and 2017

In 2017 MoNE made some updates on teacher competencies, as a result another major change was carried out. With this change, "instead of determining a subject-specific competency for each subject area, subject matter knowledge and pedagogical content knowledge have been added in the general competencies" (DGTTD, 2017:13). Thus, a single and holistic text was formed named "General Competencies of Teaching Profession". With this structure, three competency areas were composed, namely "professional knowledge", "professional skills", and "attitudes and values"; included 11 competencies and 65 indicators related to these competencies were created (DGTTD, 2017).

Within the framework of these studies carried out by MoNE; in this research, it was aimed to examine the studies in depth about music teacher competencies for primary school music teachers between the period of 2008-2017, when these competencies were in effect officially for the first time in the nation. Through this study, it is aimed to bring together the studies on music teacher competencies in Turkey. It is thought that the research will shed light on the literature in terms of revealing the needs as well as the trends related to the subject.

For this purpose, answers to the following questions were sought:

1) Which methods were used in the studies?

2) Which types of studies were used in the studies?

3) How was the distribution of sample size in the studies?

4) Which data collection tools were used in the studies?

5) What were the aims of the studies, and how was the distribution of aims in terms of competency areas?

6) What were the implications of the studies?

7) What were the recommendations of the studies?

\section{Method}

\subsection{Design}

This research aims to review and analyze studies on music teacher competencies through thematic content analysis. The thematic review, which critically synthesizes trends in studies of a field by creating themes, provides a rich source for researchers who work in the relevant field and have limited access to all studies (Çalık \& Sözbilir, 2014). For the purpose, the studies conducted between 2008 and 2017 in Turkey were scanned. And then, thematic content analysis was carried out, and parameters were determined for the thematic review. These parameters are method/model, sample group, data collection tools, aim, results, and recommendations. 


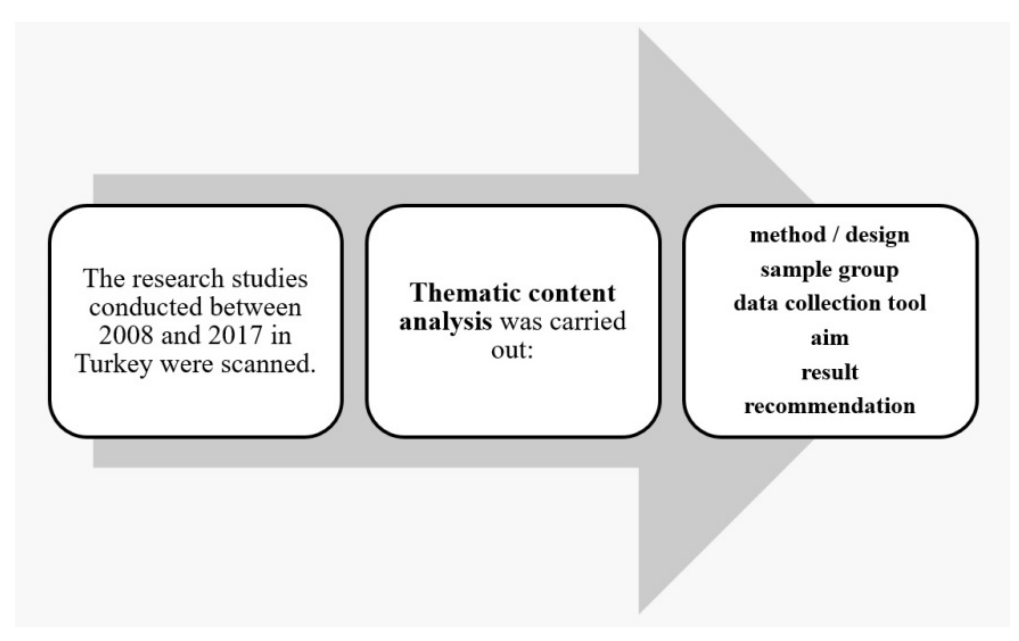

Figure 2. Design

\subsection{Data Collection and Analysis}

Data collection of this research was carried out with the e-sources system of Bursa Uludag University which provides access to national and international databases like Web of Science, EBSCO, ERIC, Sage etc. (Bursa Uludağ Üniversitesi E-Kütüphane, 2020) and the Master and PhD dissertations in Online Thesis Center of Higher Education Council which is the largest database for thesis/dissertation in Turkey (HEC, 2020) were included in the research. Therefore, both articles and theses/dissertations were covered in this research. When the studies written both as article and thesis/dissertation format, only articles were included. In addition, only authorized theses/dissertations (full text) in the Council of Higher Education Thesis Center and peer-reviewed articles were included in this research.

During the data collection process of the research, some criteria were determined for the studies to be included in the research. The first of these was related to the year the studies were conducted. As mentioned earlier, significant changes in all teacher competence areas were carried out in 2008 in Turkey. For this reason, 2008 was chosen as the starting point of this research. Since there was another major change in terms of subject specific competencies in 2017, this year was determined as the end point of the research. Therefore, articles and theses/dissertations from 2008 to 2017 were included in the research.

Another criterion that was considered in the inclusion of studies in this research was the keywords used to reach these studies. The search was carried out in Turkish language. The keywords used in the data collection process were müzik (music) and yeterlik (competence), müzik eğitimi (music education), müzik öğretmen (music teacher), müzik öğretmeni (music teacher + with many suffixes) in Turkish. In the data collection process, all possible suffixes were used together with the words due to the reason that the suffixes make differences in Turkish language. For instance, teacher means öğretmen in Turkish. But if it is intended to say teachers, there are different suffixes such as öğretmenler, öğretmenleri, öğretmenlerinin etc. Therefore, as many other forms of these words as possible were tried to use in order not to skip any of the sources. Only studies that contain these words in their titles are included in this research. In accordance with this limitation, a total of 314 studies (163 articles and 151 thesis/dissertation) were found.

The next criterion for the inclusion of the studies in the scope of this research was the samples of the studies. Since the issue of competence directly concerns teachers, it was deemed appropriate to use only studies done with music teachers in this research. Thus, the studies related to pre-service music teachers were excluded from this research. In order to determine the competency areas of the remaining studies, each study was given a score of 0 (unrelated), 1 (indirectly related), or 2 (directly related) for each of the six competency areas using the form given in the Table 1. Scoring process was carried out by two researchers. For the scoring to be reliable, the two researchers performed the scoring process independently of each other. There was no difference of more than one point between the scores given for the same research, suggesting concordance between the raters. Twenty studies (20), which have total of 2 points for any of the subject areas, are included in this research. 
Table 1. Competency areas evaluation form

\begin{tabular}{lccc}
\hline Main Competency Areas & $\begin{array}{c}\text { not related } \\
(0 \text { point })\end{array}$ & $\begin{array}{c}\text { indirectly related } \\
(1 \text { point })\end{array}$ & $\begin{array}{c}\text { directly related } \\
\text { (2 point })\end{array}$ \\
\hline Planning and regulation & & & \\
Theoretical-applied knowledge and skills & & & \\
Music culture & & & \\
Monitoring and evaluation & & & \\
School-family-society and interdisciplinary cooperation & & \\
Professional development & & \\
\hline
\end{tabular}

For the data analysis, thematic content analysis and descriptive statistics were employed. In thematic content analysis studies, specific subjects are brought together, and the research results are handled in a descriptive dimension systematically (as cited in Çalık \& Sözbilir, 2014). In this research, thematic content analysis was carried out to analyze the results and recommendations of the studies that were jointly coded by the authors; thus, themes and codes were created. The suitability of the created themes and codes was also verified by taking the opinion of an expert. Moreover, descriptive statistics were employed to find out the characteristics of the studies (method, sample size, data collection tools, etc.).

\section{Findings}

\subsection{Distribution of the Studies by Method and Design}

When the distribution of studies by method and design is examined, it is seen that quantitative methods are the most preferred ones rather than qualitative methods. As seen in table 2, there are 14 studies that used quantitative methods while 7 studies used qualitative methods in their methodologies.

Table 2. Distribution of studies by method and design

\begin{tabular}{|c|c|c|c|c|c|c|c|c|c|c|}
\hline \multirow{3}{*}{ Year } & \multicolumn{4}{|c|}{ Qualitative } & \multicolumn{4}{|c|}{ Quantitative } & \multirow{2}{*}{\multicolumn{2}{|c|}{ Total }} \\
\hline & \multicolumn{2}{|c|}{ Case Study } & \multicolumn{2}{|c|}{ Action R. } & \multicolumn{2}{|c|}{ Survey } & \multicolumn{2}{|c|}{ Correlation R. } & & \\
\hline & $f$ & $\%$ & $f$ & $\%$ & $f$ & $\%$ & $f$ & $\%$ & $f$ & $\%$ \\
\hline $2013-2017$ & 4 & 19.0 & - & - & 5 & 23.8 & 3 & 14.3 & 12 & 57.1 \\
\hline 2008-2012 & 2 & 9.5 & 1 & 4.8 & 6 & 28.6 & - & - & 9 & 42.9 \\
\hline Total & $6^{*}$ & 28.6 & 1 & 4.8 & $11^{*}$ & 52.4 & 3 & 14.3 & $21 *$ & 100 \\
\hline
\end{tabular}

* One study employed both qualitative and quantitative methods. Therefore, this study is written in both sections of the table.

Under the studies used a qualitative method, the most common design is case study ( $f=6$ ) (Ağıl, 2015; Çevik \& Güven, 2011; Çiftçi, 2008; Eldemir, 2013; Gök \& Tufan, 2016; Sönmez, 2017) whereas the least used one is action research $(f=1)$ (Kılıç, 2011). And, under the studies used quantitative method, the most commonly used methodology is the survey design ( $f=11$ ) (Aydıner \& Şen, 2011; Ayhan, 2016; Çağlak, 2008; Çiftçi, 2008; Dursun, 2015; Eroğlu, 2015; Işık, 2008; Koç, 2011; Öztürk, 2011; Şenol Sakin \& Gürgan Öztürk, 2017; Tepeköylü Öztürk \& Soytürk, 2015) while the less preferred one is correlation research $(f=3)$ (Demir \& Aydiner Uygun, 2015; İğneler, 2015; Talşı, 2016). In this research, 20 studies were analyzed however, when it is looked to the methodology side of the studies, one used mixed method in its structure (Çiftçi, 2008). Therefore, in the table, this study is shown in both qualitative and quantitative sections. The table also indicates an increase in the total number of studies in the last five years of the current research period. However, there are not many varieties found in the design of the studies (for instance, experimental study, ethnologic studies, etc.).

\subsection{Distribution of the Studies by Types}

As seen in Table 3, the number of studies between 2013 and 2017 is higher than the studies carried out between 2008 and 2013. It is seen that the articles in national journals (Aydıner \& Şen, 2011; Çevik \& Güven, 2011; Demir \& Aydıner Uygun, 2015; Eroğlu, 2015; Gök \& Tufan, 216; Kılıç, 2011; Talşık, 2016; Tepeköylü Öztürk \& Soytürk, 2015) and master thesis (Ağ1l, 2015; Ayhan, 2016; Çağlak, 2008; Dursun, 2015; Işsk, 2008; Iğneler, 2015; Koç, 2011; Öztürk, 2011; Sönmez, 2017) are higher in number from international studies. It is not surprising that national journals have more preferences because competency areas are related to the Turkish educational system. 
Table 3. Distribution of studies by types

\begin{tabular}{|c|c|c|c|c|c|c|c|c|c|c|}
\hline \multirow{3}{*}{ Year } & \multicolumn{4}{|c|}{ Article } & \multicolumn{4}{|c|}{ Thesis } & \multirow{2}{*}{\multicolumn{2}{|c|}{ Total }} \\
\hline & \multicolumn{2}{|c|}{ International } & \multicolumn{2}{|c|}{ National } & \multicolumn{2}{|c|}{ Master } & \multicolumn{2}{|c|}{$\mathrm{PhD}$} & & \\
\hline & $f$ & $\%$ & $f$ & $\%$ & $f$ & $\%$ & $f$ & $\%$ & $f$ & $\%$ \\
\hline $2013-2017$ & 2 & 10 & 5 & 25 & 5 & 25 & - & - & 12 & 60 \\
\hline $2008-2012$ & - & - & 3 & 15 & 4 & 20 & 1 & 5 & 8 & 40 \\
\hline Total & 2 & 10 & 8 & 40 & 9 & 45 & 1 & 5 & 20 & 100 \\
\hline
\end{tabular}

\subsection{Distribution of Studies by Sample Size}

Table 4 shows the sample sizes of the studies. Not surprisingly, the sample sizes of the case studies are smaller than others, while the sample sizes of survey studies are bigger.

Table 4. Distribution of studies by sample size

\begin{tabular}{|c|c|c|c|c|c|c|c|c|c|c|}
\hline \multirow{3}{*}{ Sample Size } & \multicolumn{4}{|c|}{ Qualitative } & \multicolumn{4}{|c|}{ Quantitative } & \multirow{2}{*}{\multicolumn{2}{|c|}{ Total }} \\
\hline & \multicolumn{2}{|c|}{ Case Study } & \multicolumn{2}{|c|}{ Action R. } & \multicolumn{2}{|c|}{ Survey } & \multicolumn{2}{|c|}{ Correlation R. } & & \\
\hline & $f$ & $\%$ & $f$ & $\%$ & $f$ & $\%$ & $f$ & $\%$ & $f$ & $\%$ \\
\hline $0-20$ & 3 & 14.3 & - & - & - & - & - & - & 3 & 14.3 \\
\hline $21-50$ & 1 & 4.8 & - & - & 2 & 9.5 & - & - & 3 & 14.3 \\
\hline $51-100$ & 1 & 4.8 & 1 & 4.8 & 5 & 23.8 & - & - & 7 & 33.3 \\
\hline $101-200$ & 1 & 4.8 & - & - & 2 & 9.5 & 1 & 4.8 & 4 & 19.0 \\
\hline $201-400$ & - & - & - & - & 2 & 9.5 & 2 & 9.5 & 4 & 19.0 \\
\hline Total & $6^{*}$ & 28.6 & 1 & 4.8 & $11 *$ & 52.4 & 3 & 14.3 & $21 *$ & 100 \\
\hline
\end{tabular}

* One study employed both qualitative and quantitative methods. Therefore, this study is included in both sections of the table.

\subsection{Distribution of the Studies by Data Collection Tool}

As seen in table 5, the data collection tools are mostly in a questionnaire format ( $\mathrm{f}=8$ ) (Aydıner \& Sen, 2011; Ayhan, 2016; Çağlak, 2008; Çiftçi, 2008; Eroğlu, 2015; Işık, 2008; Koç, 2011; Şenol Sakin \& Gürgan Öztürk, 2017). The scales (f=6) (Demir \& Aydıner Uygun, 2015; Dursun, 2015; İğneler, 2015; Öztürk, 2011; Talşı, 2016; Tepeköylü Öztürk \& Soytürk, 2015) and interviews (f=6) (Ağıl, 2015; Çevik \& Güven, 2011; Çiftçi, 2008; Eldemir, 2013; Gök \& Tufan, 2016; Sönmez, 2017) are also the commonly preferred tools in the studies.

Table 5. Distribution of the studies by data collection tool

\begin{tabular}{lcc}
\hline Data collection tool & $f$ & $\%$ \\
\hline Questionnaire & 8 & 36.3 \\
Scale & 6 & 27.3 \\
Interview fmorm & 6 & 27.3 \\
Assessment form of the course & 1 & 4.5 \\
Check list & 1 & 4.5 \\
\hline Total & $22 *$ & 100 \\
\hline
\end{tabular}

*More than one tool is used in some studies.

\subsection{Distribution of the Aims of the Studies by Main Competency Areas}

Table 6 shows the distribution of the aims of the studies by main competency areas. The aims of the studies are classified according to the main competency areas. 
Table 6. Distribution of the aims of the studies by main competency areas

\begin{tabular}{|c|c|c|c|c|c|c|}
\hline \multirow[t]{2}{*}{ Aim of the Study } & \multicolumn{6}{|c|}{$\begin{array}{c}\text { Main Competency } \\
\text { Areas } \\
\end{array}$} \\
\hline & 1 & 2 & 3 & 4 & 5 & 6 \\
\hline To determine the preference and reasons for preference of recorder or melodica as a classroom instrument. & $\mathrm{x}$ & $\mathrm{x}$ & & & & \\
\hline To prepare a curriculum, including diaphragmatic breathing exercises. & $\mathrm{x}$ & $\mathrm{x}$ & & & & \\
\hline To determine the contributions of piano training at the undergraduate level to the music teaching profession. & $\mathrm{x}$ & $\mathrm{x}$ & & & & \\
\hline To determine to what extend music teachers benefit the instruments in their profession. & $\mathrm{x}$ & $\mathrm{x}$ & & & & \\
\hline To determine music teachers' opinions about their competencies in traditional Turkish art music. & $\mathrm{x}$ & $\mathrm{x}$ & $\mathrm{x}$ & & & \\
\hline To determine to what extend Turkish folk instruments are used in music classes. & $\mathrm{x}$ & $\mathrm{x}$ & $\mathrm{x}$ & & & \\
\hline To determine to what extend music teachers benefit the bağlama in music classes. & $\mathrm{x}$ & $\mathrm{x}$ & $\mathrm{x}$ & & & \\
\hline To evaluate the teachers' opinions on music teaching curriculum. & $\mathrm{x}$ & $\mathrm{x}$ & & & & $\mathrm{x}$ \\
\hline To determine the sufficiency of harmony knowledge and skill of music teachers. & $\mathrm{x}$ & $\mathrm{x}$ & & & & $\mathrm{x}$ \\
\hline To determine teachers' opinions on their ability to play accompaniment for school songs. & $\mathrm{x}$ & $\mathrm{x}$ & & & & $\mathrm{x}$ \\
\hline To determine the music teachers' preference level of teaching styles. & $\mathrm{x}$ & $\mathrm{x}$ & & & & $\mathrm{x}$ \\
\hline To determine the music teachers' state of using multiple intelligence theory in their classes. & $\mathrm{x}$ & $\mathrm{x}$ & & & & $\mathrm{x}$ \\
\hline $\begin{array}{l}\text { To determine the movement-based learning activities employed in music teaching and to create a repertoire of } \\
\text { these activities. }\end{array}$ & $\mathrm{x}$ & $\mathrm{x}$ & & & & $\mathrm{x}$ \\
\hline To determine the teachers' opinions on music education of inclusive students. & $\mathrm{x}$ & & $\mathrm{x}$ & & & $\mathrm{x}$ \\
\hline $\begin{array}{l}\text { To determine the teachers' opinions on school instrument courses taught at the undergraduate level and use the } \\
\text { knowledge and skills acquired in those courses in their profession. }\end{array}$ & $\mathrm{x}$ & $\mathrm{x}$ & $\mathrm{x}$ & $\mathrm{x}$ & & $\mathrm{x}$ \\
\hline To determine the relationship between professional competence, satisfaction, and burnout. & $\mathrm{x}$ & $\mathrm{x}$ & $\mathrm{x}$ & $\mathrm{x}$ & $\mathrm{x}$ & $\mathrm{x}$ \\
\hline To examine the communication skill levels of physical education, music, and visual arts teachers. & & & & & $\mathrm{x}$ & \\
\hline $\begin{array}{l}\text { To determine the relationship between music teachers' professional competency perceptions and their life and job } \\
\text { satisfaction. }\end{array}$ & & & & & & $\mathrm{X}$ \\
\hline To determine the level of music teachers' burnout. & & & & & & $\mathrm{x}$ \\
\hline To determine music teachers' needs in terms of in-service training by asking their opinions. & & & & & & $\mathrm{x}$ \\
\hline
\end{tabular}

1: Planning and regulation, 2: Theoretical-applied knowledge and skills, 3: Music culture, 4: Monitoring and evaluation, 5: School-family-society and interdisciplinary cooperation, 6: Professional development

\subsection{Frequencies of Main Competency Areas in the Studies}

Table 7 shows the frequencies of the main competency areas in the studies. As it is seen, the most of the studies concerned are particularly relevant to planning and regulation; and theoretical-applied knowledge and skills areas that are followed by the professional development competency areas.

Table 7. Frequencies of main competency areas in the studies

\begin{tabular}{lcc}
\hline Main Competency Areas & $f$ & $\%$ \\
\hline Planning and regulation & 16 & 80 \\
Theoretical-applied knowledge and skills & 15 & 75 \\
Music culture & 6 & 30 \\
Monitoring and evaluation & 2 & 10 \\
School-family-society and interdisciplinary cooperation & 2 & 10 \\
Professional development & 12 & 60 \\
\hline
\end{tabular}

\subsection{The Results of the Studies}

This part of the research was compiled by the thematic content analysis. After analyzing the results of the studies, seven themes were determined. Later, codes were formed by examining the most frequent topics discussed under the related themes.

The first of the seven themes is named "undergraduate courses" and this theme has one code, named "inadequate courses". As seen in Table 8, in the studies under this theme, music teachers commented on the inadequate undergraduate courses such as accompaniment, piano, bağlama and school instruments like Orff instruments, melodica, mandolin, etc. (Aydıner \& Şen, 2011; Çağlak, 2008; Çevik \& Güven, 2011; Çiftçi, 2008; Koç, 2011; Öztürk, 2011). 
Table 8 . The results of the "undergraduate courses" theme

\begin{tabular}{cll}
\hline Theme & \multicolumn{1}{c}{ Code } & \multicolumn{1}{c}{ Results } \\
\hline & & Accompaniment \\
Undergraduate Courses & Inadequate Courses & School Instruments (Orff instruments, recorder, melodica, mandolin, etc.) \\
& & Piano \\
& Bağlama \\
\hline
\end{tabular}

Table 9 shows the second theme, "instrument usage". Under this theme, three codes are found. These are "school instruments", "accompaniment", and "main instrument" (strings, wind instruments, etc.). The studies discussed that most of the teachers integrate school instruments into their teaching (Koç, 2011). But studies showed that teachers do not use their main instruments adequately in the schools (Çağlak, 2008). Also, it was discussed that accompany instruments like piano, guitar, etc. are not able to be used effectively by the music teachers (Aydiner \& Şen, 2011; Çevik \& Güven, 2011; Şenol Sakin \& Gürgan Öztürk, 2017).

Table 9. The results of the "instrument usage" theme

\begin{tabular}{|c|c|c|}
\hline Theme & Code & Results \\
\hline \multirow{6}{*}{$\begin{array}{l}\text { Instrument } \\
\text { Usage }\end{array}$} & \multirow{3}{*}{ School Instruments* } & Most of the teachers integrate school instruments into their teaching. \\
\hline & & $\begin{array}{l}\text { The instruments taught in school instrument courses (melodica or recorder) do not } \\
\text { affect teachers' instrument preferences. }\end{array}$ \\
\hline & & $\begin{array}{l}\text { Teachers in state schools prefer melodica and recorder equally, while melodica is } \\
\text { more common in private schools. }\end{array}$ \\
\hline & \multirow{2}{*}{ Accompaniment } & Teachers have problems playing accompaniment. \\
\hline & & Most of the teachers do not benefit from the piano adequately. \\
\hline & $\begin{array}{l}\text { Main Instruments (Strings, Wind } \\
\text { Instruments, Etc.) }\end{array}$ & $\begin{array}{l}\text { Teachers do not use their instruments adequately. } \\
\text { According to the teachers, the content of the piano courses given in undergraduate } \\
\text { education does not meet the teachers' needs. }\end{array}$ \\
\hline
\end{tabular}

* The curriculum of Music Education Departments includes a course named School Instruments. In this course, various instruments commonly used in music teaching at schools such as recorder, Orff instruments, guitar, and mandolin (Bursa Uludağ University [BUU], 2021; HEC, 2007; HEC, 2018).

The third theme is the "traditional instrument usage". Under this theme, two codes are found: "Traditional instruments" and "bağlama". Bağlama is also a traditional Turkish instrument however, there are some studies that covered bağlama separately while some of the studies discussed traditional instruments in general. In the results of the studies, teachers commented that bağlama is very important instrument for the music courses. But since the most of the teachers are not trained on bağlama, they claimed that they are not able to use the instrument adequately (Aydıner \& Şen, 2011). The results of the studies also showed that teachers discussed the inadequacy of bağlama education in undergraduate degree programs (Iş̧1, 2008).

Table 10. The results of the "traditional instrument usage" theme

\begin{tabular}{|c|c|c|}
\hline Theme & Code & Results \\
\hline \multirow{4}{*}{$\begin{array}{c}\text { Traditional Instrument } \\
\text { Usage }\end{array}$} & $\begin{array}{l}\text { Traditional Instruments } \\
\text { (General) }\end{array}$ & $\begin{array}{l}\text { Almost a quarter of the teachers do not study Turkish music instruments during } \\
\text { undergraduate education. } \\
\text { Half of the teachers use Turkish folk instruments in music lessons. }\end{array}$ \\
\hline & \multirow{3}{*}{ Bağlama } & Most of the teachers have been educated on bağlama. \\
\hline & & Teachers do not play bağlama adequately in their professional lives. \\
\hline & & Teachers find the bağlama education in undergraduate inadequate. \\
\hline
\end{tabular}

As seen in table 11, the fourth theme is "theoretical knowledge". This theme has one code named "usage of theory in practice". According to the results of the studies, music teachers found their music theory and harmony knowledge and skills inadequate (Eroğlu, 2015). And depending on this, most of them have difficulties in playing accompaniment (Çevik \& Güven, 2011). 
Table 11. The results of the "theoretical knowledge" theme

\begin{tabular}{cll}
\hline Theme & Code & Results \\
\hline \multirow{2}{*}{ Theoretical Knowledge } & Usage of Theory in Practice & Music teachers find their harmony knowledge and skills inadequate. \\
& & The majority of teachers have difficulties in playing accompaniment \\
\hline
\end{tabular}

Table 12 shows the fifth theme, "in-service training". This theme has three codes, which are "quality of in-service training", "quantity of in-service training", and "content of in-service training". Studies discussed that most of the teachers consider the in-service training inadequate in terms of quality and quantity. Teachers expressed their wish to have in-service training provided by academicians especially on the topics of playing school instruments, voice education, musician health care, current curriculum, and etc. (Ağıl, 2015; Ayhan, 2016; Çiftçi, 2008; Dursun, 2015; Eroğlu, 2015; Gök \& Tufan, 2016; Kılıç, 2011; Sönmez, 2017; Talşık, 2016).

Table 12. The results of the "in-service training" theme

\begin{tabular}{|c|c|c|}
\hline Theme & Code & Results \\
\hline \multirow{6}{*}{$\begin{array}{l}\text { In-Service } \\
\text { Training }\end{array}$} & \multirow{4}{*}{$\begin{array}{l}\text { Quality of In-Service } \\
\text { Training }\end{array}$} & In-service training is inadequate in terms of quality. \\
\hline & & $\begin{array}{l}\text { Expert music educators are not consulted enough during the planning and preparation of } \\
\text { in-service training content. }\end{array}$ \\
\hline & & $\begin{array}{l}\text { There is no functional assessment in in-service training programs, which affects the programs' } \\
\text { efficiency negatively. }\end{array}$ \\
\hline & & In-service training is requested to be provided by academicians. \\
\hline & $\begin{array}{l}\text { Quantity of In-Service } \\
\text { Training }\end{array}$ & $\begin{array}{l}\text { In-service training is inadequate in terms of quantity. } \\
\text { Teachers want conferences, workshops, seminars, and sample lesson activities given in } \\
\text { in-service training to be distributed as DVDs to schools. }\end{array}$ \\
\hline & $\begin{array}{l}\text { Content of In-Service } \\
\text { Training }\end{array}$ & $\begin{array}{l}\text { Teachers want to be trained in playing practical instruments } \\
\text { Teachers need courses about voice and musician health care. } \\
\text { Teachers want the curriculum to be introduced via in-service training. }\end{array}$ \\
\hline
\end{tabular}

Table 13 shows the sixth theme, "professional competence". There are two codes under this theme, "perception of professional proficiency" and "student-centered approach". Regarding the perception of professional proficiency, studies discussed that teachers who think their knowledge and skills are inadequate have more burnout. Also, experience in the profession increases the perception of professional competence (Talş1k, 2016). In the second code of this theme, which is called student-centered approach, studies reported that teachers found their level of knowledge about constructivist learning theory insufficient, and depending on this, the majority of them think they did not understand enough the applications of the renewed elementary music-teaching program (Gök \& Tufan, 2016). Also, studies found that teachers did not have enough experience about "musical creativity" (Ağ1l, 2015).

Table 13. The results of the "professional competence" theme

\begin{tabular}{|c|c|c|}
\hline Theme & Code & Results \\
\hline & $\begin{array}{c}\text { Perception of Professional } \\
\text { Proficiency }\end{array}$ & $\begin{array}{l}\text { Teachers who think their knowledge and skills are inadequate have more burnout. } \\
\text { Experience in the profession increases the perception of professional competence. } \\
\text { There is a relationship between perceptions of professional competence level and life } \\
\text { satisfaction and general job satisfaction levels. }\end{array}$ \\
\hline $\begin{array}{l}\text { Professional } \\
\text { Competence }\end{array}$ & Student-Centred Approach & $\begin{array}{l}\text { The majority of teachers think they do not understand enough of the renewed } \\
\text { elementary music-teaching program. } \\
\text { Teachers find their level of knowledge about constructivist learning theory insufficient } \\
\text { Teachers do not have comprehensive knowledge of the theory of multiple intelligences. } \\
\text { Teachers do not use movement-based learning activities enough in their lessons. } \\
\text { Teachers do not have enough experience about "musical creativity". } \\
\text { The more the number of students increases in a class, the more the teachers turn from } \\
\text { the student-centered teaching styles into teacher-centered teaching styles. }\end{array}$ \\
\hline
\end{tabular}

The last theme given in Table 14 is "special education". It has one code, which is called "inclusive education". 
According to the results of the studies, teachers asserted that they had no courses related to inclusive education during their undergraduate degree at the university, therefore they feel inadequate for this area (Sönmez, 2017).

Table 14. The results of the "special education" theme

\begin{tabular}{ccl}
\hline Theme & Code & \multicolumn{1}{c}{ Results } \\
\hline & & Teachers did not take courses related to inclusive education during their undergraduate degree at the \\
Special & Inclusive & Teachers feel inadequate about inclusive education. \\
Education & Education & Teachers do not allocate extra time for mainstreaming students. \\
& & Most of them do not prepare individualized education programs. \\
&
\end{tabular}

\subsection{Recommendations of the Studies}

For the recommendations of the studies, four themes were formed. Table 15 shows the first theme, "undergraduate education". There are three codes under this theme, which are called "theoretical courses", "instrument courses", and "teaching profession". In general, under this theme, studies recommended topics such as more theoretical courses, more instrument courses, more movement-based exercises. Under the first code called "theoretical courses", studies suggested the revisions of the syllabus of music theory and accompaniment courses and hours of these courses (Çevik \& Güven, 2011; Eroğlu, 2015; Öztürk, 2011). According to the second code of the theme called "instrument courses", similar recommendations made for bağlama and piano courses (Aydıner \& Şen, 2011; Çağlak, 2008; Işık, 2008). The syllabus of major instrument courses also recommended a revision according to the needs of the profession. In addition, studies showed that the number of Turkish folk instrument courses should be increased (Aydıner \& Şen, 2011; Çağlak, 2008; Işık, 2008) and the process of measurement and evaluation of the performance should be included in the instrument courses (Koç, 2011). According to recommendations on the "teaching profession" code, more activities about the profession, and more movement-based activities in the syllabus of Play-Dance-Music courses were suggested (Ağll, 2015). Also, it was recommended that pre-service teachers need to be given opportunities to gain experience at schools where inclusive education takes place (Sönmez, 2017).

Table 15. Recommendations of the studies about the "undergraduate education" theme

\begin{tabular}{|c|c|c|}
\hline Theme & Code & Recommendations \\
\hline \multirow{4}{*}{$\begin{array}{c}\text { Undergraduate } \\
\text { Education }\end{array}$} & $\begin{array}{c}\text { Theoretical } \\
\text { Courses }\end{array}$ & $\begin{array}{l}\text { The syllabus of courses on music theory should be revised, and the hours of these courses } \\
\text { should be increased. } \\
\text { The syllabus of accompaniment courses should be revised, and the hours of these courses } \\
\text { should be increased. } \\
\text { Practices on accompaniment should be included in the syllabus of the music theory courses }\end{array}$ \\
\hline & & $\begin{array}{l}\text { The number of Turkish folk instrument courses should be increased. } \\
\text { The syllabus of bağlama courses should be revised, and the hours of these courses should be } \\
\text { increased. }\end{array}$ \\
\hline & $\begin{array}{c}\text { Instrument } \\
\text { Courses }\end{array}$ & $\begin{array}{l}\text { The syllabus of piano courses should be revised according to the needs of the profession. } \\
\text { The syllabus of major instrument courses should be revised according to the needs of the } \\
\text { profession. } \\
\text { In the instrument courses, the process of measurement and evaluation of the performance should } \\
\text { be included in the curriculum. }\end{array}$ \\
\hline & $\begin{array}{l}\text { Teaching } \\
\text { Profession }\end{array}$ & $\begin{array}{l}\text { There should be more activities about the profession. } \\
\text { There should be more movement-based activities in the syllabus of Play-Dance-Music courses. } \\
\text { Pre-service teachers should be given opportunities to gain experience at schools where inclusive } \\
\text { education takes place. } \\
\text { Drama education should be included. }\end{array}$ \\
\hline
\end{tabular}

Table 16 shows another theme, "materials". There is only one code related to this theme, which is called "teaching materials". Studies recommended that examples of different teaching styles should be given in the music teacher's guidebook and teaching materials for school instruments should be prepared and shared with music teachers (Demir \& Uygun, 2015; Şenol Sakin \& Gürgan Öztürk, 2017). 
Table 16. Recommendations of the studies about the "material" theme

\begin{tabular}{ccl}
\hline Theme & \multicolumn{1}{c}{ Code } & \multicolumn{1}{c}{ Recommendations } \\
\hline Materials & Teaching materials & $\begin{array}{l}\text { Examples of different teaching styles should be given in the music teacher's guidebook. } \\
\text { Teaching materials for school instruments should be prepared and shared with music teachers. }\end{array}$ \\
\hline
\end{tabular}

The third theme showed in Table 17 is "policies". Under this theme, there are two codes called "cooperation" and "others". Regarding the cooperation code, studies indicated that MoNE should cooperate more with the education faculties (Çağlak, 2008). In addition to this, studies suggested that policies should be developed to increase the level of life and job satisfaction of music teachers so that music teachers' working conditions should be improved (Dursun, 2015).

Table 17. Recommendations of the studies about "policies" theme

\begin{tabular}{ccl}
\hline Theme & Code & \multicolumn{1}{c}{ Recommendations } \\
\cline { 2 - 3 } Policies & Cooperation & MoNE should cooperate more with the education faculties. \\
\cline { 2 - 3 } & Others & $\begin{array}{l}\text { Policies should be developed to increase the level of life and job satisfaction of music teachers. } \\
\text { The working conditions of music teachers should be improved. }\end{array}$ \\
\hline
\end{tabular}

Table 18 shows the fourth and the last theme, "in-service training". There are two codes which are called "the required subjects" and "others". Studies reported that teachers needed in-service training for the subjects of music theory, traditional Turkish folk music, movement-based learning activities, multiple intelligence theory, constructivism, special education, creative drama, teaching styles, and profession competences (Ağıl, 2015; Ayhan, 2016; Dursun, 2015; Eroğlu, 2015; Gök \& Tufan, 2016; Kılıç, 2011; Sönmez, 2017; Talşık, 2016). The other recommendation about the in-service training is about the need analysis which should be done by using scientific methods on in-service training (Çiftçi, 2008).

Table 18. Recommendations of the studies about "in-service training" theme

\begin{tabular}{|c|c|c|}
\hline Theme & Code & Recommendations \\
\hline \multirow{12}{*}{ In-service Training } & \multirow{9}{*}{ The required subjects } & Music theory \\
\hline & & Traditional Turkish folk music \\
\hline & & Movement-based learning activities \\
\hline & & Multiple intelligence theory \\
\hline & & Constructivism \\
\hline & & Special education \\
\hline & & Creative drama \\
\hline & & Teaching styles \\
\hline & & Profession competencies \\
\hline & \multirow{3}{*}{ Others } & The number and hours of in-service training should be increased. \\
\hline & & In-service training should be improved. \\
\hline & & The need analysis should be done by using scientific methods on in-service training. \\
\hline
\end{tabular}

\section{Discussion, Conclusion, and Recommendation}

In this research, it was aimed to examine and evaluate thematically the studies on music teacher competencies, which were in effect between 2008 and 2017. In this context, studies conducted during this period were included in the research process, taking into account some criteria such as keywords, sample group of the studies, etc. As a result of the search with the determined keywords, a total of 314 studies were reached. Among them, it was seen that most of the studies were either discussing the self-efficacy perceptions about profession and pedagogical content knowledge areas (Akbulut, 2012; Dursun, 2015; Talşık, 2016) or the relationship between teaching self-efficacy and various variables such as gender, class degree, academic achievement, music teacher competencies etc. (Birer \& Sonsel, 2013; Deniz \& Kürücü, 2019; Güleryüz \& Demirci, 2016; Şeker, 2017; Tunç \& Bulut, 2016; Yağcı \& Aksoy, 2015; Yokuş, 2014). One of the other important criteria for the inclusion of the studies in the scope of this research was the samples of the studies consisted of music teachers. The surprising result was that only 20 of these studies were conducted with music teachers. Studies other than these 20 were 
mostly conducted with music teacher candidates. Even this finding obtained at the first stage of the research can be considered a striking finding because it shows that a very small part of the studies on a subject that directly concerns music teachers were done with music teachers. The reason for the preference of music teacher candidates can be explained by easy access to this sample group by researchers. It is not always easy to reach music teachers because of the processes related to the permissions for the research. Since the competencies are directly related to teachers, studies done with music teachers should be increased to get stronger and reliable results about the current situation of the field. So, it is recommended for researchers to conduct research into the real environment of the music teacher.

When it is looked at the studies' in general, it is seen that most of the studies used the descriptive survey design and the case study design. Also, data collection tools were mostly in the form of survey, scale and interview. As it is known that the studies which used descriptive or case designs are mostly involve revealing or determining the existing situation. So, many topics and problems about the music teacher competencies were revealed using these kinds of studies. For future studies, these studies can be considered as preliminary studies. However, it is recommended that different types of researches should be developed and enriched by using different methods or research designs. Besides conducting various kinds of studies, it can also be suggested to develop some projects with the collaboration of researchers and relevant people in the field. In this way, the competency areas can be handled in different directions.

When it is looked to the studies about the competency areas, it is seen that they are mostly related to planning and regulation, the theoretical applied knowledge and skill and professional development. Other competency areas like music culture, monitoring and evaluation and school-family-society and interdisciplinary cooperation are not studied in depth. This can be the reason that more theory-based education in Turkey is given and education focuses more on planning and regulation of the profession. Therefore, it can be suggested that all mentioned competency areas should be equally studied in order to improve music teaching competency areas.

When it is looked at the studies overall, the studies were mostly pointed out both the inadequacy of some courses in the undergraduate program and the required subjects in the in-service training. Regarding this problem, which is often referred to in the studies, course contents (especially the courses of school instruments, accompaniment, piano and bağlama) in music education programs can be revised to suit the needs of teachers (Aydıner \& Şen, 2011; Çevik \& Güven, 2011; Eldemir, 2013; Şenol Sakin \& Gürgan Öztürk, 2017). Another result frequently mentioned in the studies, teachers feel inadequate themselves about the student-centered approach and musical creativity (A $\breve{g l} 1,2015$; Gök \& Tufan, 2016). So, even if teachers mostly consider themselves highly competent professionally (Akbulut, 2012), teachers who think their knowledge and skills are inadequate have more burnout (Talşı, 2016). According to these findings, it is suggested that the courses in the program require to be more functional for both undergraduate program and in-service training.

Through this research, it was aimed to bring together the studies related to music teacher competencies in Turkey and to find out what they focus on. As a result, together with a holistic view about the teacher competencies, general information about studies carried out in the field of music teacher competencies in Turkey was provided. Thus, by giving an opportunity to evaluate the researches from a thematic aspect, the most common problems were identified and various new ideas for new studies were presented.

\section{References}

Ağıl, M. (2015). Ortaokul Müzik derslerinde müzik öğretmenlerinin kullandıkları harekete dayalı öğrenme etkinlikleri (Tokat ili örneği). Tokat: Gaziosmanpaşa University Institute of Educational Sciences.

Akbulut, E. (2012). Müzik öğretmenleri mesleki yeterlikleri ölçeği çalışması. NWSA-Fine Arts, 7(4), 334-346. Retrieved from https://dergipark.org.tr/tr/pub/nwsafine/issue/19894/213052

Aydıner, M., \& Şen, Y. (2011). Geleneksel Türk halk çalgılarının müzik öğretmenleri tarafından kullanılma durumu. Milli Folklor, 23(91), 140-149.

Ayhan, A. (2016). Müzik ögretmenlerinin çoklu zeka kuramını uygulama durumlarının incelenmesi (Sakarya ili örneği). İstanbul: Marmara University Institute of Educational Sciences.

Begic, J. S., Begic, A., \& Skojo T. (2017). Opinions of university music teachers on the musical competencies necessary for primary education teachers. International Journal of Higher Education, 6(1), 197-208. https://doi.org/10.5430/ijhe.v6n1p197

Bernard, R. (2009). Uncovering pre-service music teachers' assumptions of teaching, learning, and music. Music Education Research, 11(1), 111-124. https://doi.org/10.1080/14613800802700974 
Birer, A. R. H., \& Sonsel, Ö. B. (2013). Müzik öğretmeni adaylarının mesleki öz-yeterlik durumlarının çeşitli değişkenler açısından incelenmesi: Selçuk Üniversitesi örneği. NWSA-Fine Arts, 8(4), 389-398. https://doi.org/10.12739/NWSA.2013.8.4.D0142

Bisschoff, T., \& Grobler, B. (1998). The managementof teacher competence. Journal of In-Service Education, 24(2), 191-211. https://doi.org/10.1080/13674589800200041

Bursa Uludağ Üniversitesi E-Kütüphane. (2020, November). Resources. Retrieved from https://uludag.app.deepknowledge.io/resources

Bursa Uludağ University [BUU]. (2021). Müzik Öğretmenliği. Bilgi Paketi \& Ders Kataloğu. Retrieved from http://bilgipaketi.uludag.edu.tr/Programlar/Detay/349?AyID=25\#Dersler

Çağlak, E. (2008). Van ilinde görev yapan müzik öğretmenlerinin slnıf ortamında çalgllardan yararlanma durumlart. Van: Yüzüncü Yıl University Institute of Social Sciences.

Çalık, M., \& Sözbilir, M. (2014). İçerik Analizinin Parametreleri. Education and Science, 39(174), 33-38. https://doi.org/10.15390/EB.2014.3412

Çevik, D. B., \& Güven, E. (2011). İlköğretim müzik öğretmenlerinin okul şarkılarına piyanoda eşlik yapabilme konusuna ilişkin görüşleri üzerine bir çalışma. Balıkesir University Institute of Social Sciences Journal, 14(25), 86-98. Retrieved from https://dergipark.org.tr/tr/pub/baunsobed/issue/50199/646430

Cho, E. J., \& Cho, H. S. (2021). The development and effects of the PBL-based early childhood music education program for enhancing the music teaching competency of early childhood pre-service teachers. Early Childhood Education Research \& Review, 25(1), 87-110. https://doi.org/10.32349/ECERR.2021.2.25.1.87

Çiftçi, E. (2008). Türkiye'de Millî Ĕgitim Bakanlı̆̆ tarafindan müzik öğretmenlerine verilen hizmet içi eğitimin incelenmesi ve müzik öğretmenlerinin hizmet içi eğitim ihtiyaçlarının belirlenmesi. Ankara: Gazi University Institute of Educational Sciences.

Davis, V. W. (2006). Beginning music education students' and student teachers' opinions of skills and behaviors important to successful music teaching. Contributions to Music Education, 33(1), 27-40. Retrieved from http://www.jstor.org/stable/24127198

Demir, B., \& Aydıner Uygun, M. (2015). Müzik öğretmenlerinin öğretim stillerini tercih etme düzeylerinin incelenmesi. Pegem Journal of Education and Instruction, 5(5), 469-484. https://doi.org/10.14527/pegegog.2015.026

Denis, J. M., \& Tucker, O. G. (2021). Acquiring competency in music, teaching, and personal skill areas: A survey of in-service teachers. Contributions to Music Education, 46, 35-52. Retrieved from https://www.proquest.com/scholarly-journals/acquiring-competency-music-teaching-personal/docview/254 $3520432 / \mathrm{se}-2$ ?accountid=17219

Deniz, J., \& Kürücü, N. (2019). Müzik öğretmeni adaylarının müzik öğretimi öz yeterlilik algılarının incelenmesi. The Journal of Social Sciences, 34(34), 112-126. https://doi.org/10.16990/SOBIDER.4799

Directorate General for Teacher Training and Development [DGTTD]. (2008). Müzik Öğretmeni Özel Alan Yeterlikleri. Retrieved from http://oygm.meb.gov.tr/meb_iys_dosyalar/2017_11/06160625_10-YYretmen_ Yeterlikleri_KitabY_mYzik_YYretmeni_Yzel_alan_yeterlikleri_ilkYYretim_parYa_13.pdf

Directorate General for Teacher Training and Development [DGTTD]. (2017). General competencies for teaching profession. Retrieved from http://oygm.meb.gov.tr/meb_iys_dosyalar/2018_06/29111119_Teachers GeneralCompetencies.pdf

Dörge C. (2010). Competencies and skills: Filling old skins with new wine. In N. Reynolds, \& M. Turcsányi-Szabó (Eds.), Key Competencies in the Knowledge Society, 324 (pp. 78-89). https://doi.org/10.1007/978-3-642-15378-5_8

Dubrovina, I., Moskalenko, T., \& Zinchenko, O. (2020). Professional development of future teacher: Competency approach. Cherkasy University Bulletin: Pedagogical Sciences, 111-118. https://doi.org/10.31651/2524-2660-2020-2-111-118

Dursun, Y. (2015). Müzik öğretmenlerinin mesleki yeterlik alglları ile yaşam ve iş doyumları arasındaki ilişki. İstanbul: Marmara University Institute of Educational Sciences.

Elaldı, Ş., Batdı, V., \& Sönmez-Ölger, D. (2020). Music education competencies of preschool teachers and preservice preschool teachers. Cumhuriyet International Journal of Education, 9(2), 617-636. 
Eldemir, A. C. (2013). Öğretmen yeterlikleri kapsamında müzik öğretmenlerinin geleneksel Türk sanat müziği alanındaki yeterlikleri. E-Journal of New World Sciences Academy, 8(2), 196-205. https://doi.org/10.12739/NWSA.2013.8.2.D0128

Eroğlu, Ö. (2015). Eğitim Fakültesi mezunu müzik öğretmenlerinin armoni bilgi ve becerilerine ilişkin görüşleri. Bartin University Journal of Faculty of Education, 4(2), 319-330. https://doi.org/10.14686/buefad.v4i2.5000143436

Gök, M., \& Tufan, E. (2016). Müzik öğretmenlerinin 2006 ilköğretim Müzik dersi öğretim programına ilişkin görüşleri (Ankara örneği). Kastamonu Education Journal, 24(3), 1385-1402. Retrieved from https://dergipark.org.tr/tr/pub/kefdergi/issue/22607/241626

Güleryüz, Ş., \& Demirci, B. (2016). Müzik öğretmeni adaylarının özel alan yeterliklerinin incelenmesi. International Journal of Social Science, 47, 103-119. https://doi.org/10.9761/JASSS3418

Hallam, S., Robertson, A., Saleh, C., Rogers, L., Burnard, P., Davies, V., \& Kokatsaki, D. (2009). Trainee primary-school teachers' perceptions of their effectiveness in teaching music. Music Education Research, 11(2), 221-240. https://doi.org/10.1080/1461380090292450

Hash, P. M. (2010). Preservice classroom teachers' attitudes toward music in the elementary curriculum. Journal of Music Teacher Education, 19(2), 6-24. https://doi.org/10.1177/1057083709345632

Higher Education Council [HEC]. (2007). Eğitim Fakültesi Öğretmen Yetiştirme Lisans Programları. Retrieved from https://www.yok.gov.tr/Documents/Yayinlar/Yayinlarimiz/egitim-fakultesi-ogretmen-yetistirme-lisansprogramlari.pdf

Higher Education Council [HEC]. (2018). Müzik Öğretmenliği Lisans Programı. Retrieved from https://www.yok.gov.tr/Documents/Kurumsal/egitim_ogretim_dairesi/Yeni-Ogretmen-Yetistirme-Lisans-Pr ogramlari/Muzik_Ogretmenligi_Lisans_Programi.pdf

Higher Education Council [HEC]. (2020, November). Thesis Center. Retrieved from https://tez.yok.gov.tr/UlusalTezMerkezi/giris.jsp

İğneler, K. Ö. (2015). Müzik öğretmenlerinin mesleki tükenmişlik düzeylerinin belirlenmesi (Gaziantep il örneği). Gaziantep: Zirve University Institute of Social Sciences.

Işı, H. (2008). Ilköğretim ve ortaögretimde görev yapan müzik öğretmenlerinin bağlama kullanimlarinin incelenmesi. Ankara: Gazi University Educatinal Sciences Institute.

Kaleli, Y. S. (2020). Investigation of the relationship between pre-service music teachers' attitudes towards teaching profession and their self-efficacy beliefs. International Journal of Research in Education and Science (IJRES), 6(4), 580-587. https://doi.org/10.46328/ijres.v6i4.1493

Kılıç, I. (2011). Müzik öğretim yöntemlerinin yaratıcı dramayla birlikte kullanılması: Diyafram nefesi ve ses çalışmaları alt öğrenme alanında bir uygulama örneği. Ondokuz Mayls University Journal of Faculty Education, 30(2), 29-53. Retrieved from https://dergipark.org.tr/tr/pub/omuefd/issue/20249/214843

Koç, A. (2011). Eğitim Fakülteleri Müzik Eğitimi A.B.D. ders programlarında yer alan okul çalglları dersinin müzik ögretmenlerinin görüşlerine dayall olarak incelenmesi. Ankara: Gazi University Institute of Educational Sciences.

Koca, Ş. (2017). Competencies of music teacher candidates taking pedagogical formation training. International Online Journal of Educational Sciences, 9(2), 370-380. https://doi.org/10.15345/iojes.2017.02.006

Kowalczuk-Walêdziak, M., Korzeniecka-Bondar, A., Danilewicz, W., \& Lauwers, G. (Eds.). (2019). Rethinking teacher education for the 21st century: Trends, challenges and new directions (1st ed.). V. B. Budrich. https://doi.org/10.2307/j.ctvpb3xhh

Küçük, D. P. (2012). Müzik öğretmenlerinin müzik öğretmenliği mesleğine yönelik tutumları. Dicle Üniversitesi Ziya Gökalp Eğitim Fakültesi Dergisi, 19, 151-161. Retrieved from https://dergipark.org.tr/tr/pub/zgefd/issue/47945/606602

Menter, I. (2016). Helga Eng lecture 2015: What is a teacher in the 21st century and what does a 21st century teacher need to know? Acta Didactica Norge, 10(2), 11-25. https://doi.org/10.5617/adno.2647

Organisation for Economic Cooperation and Development [OECD]. (2009). Teacher evaluation: A conceptual framework and examples of country practices. Retrieved from https://www.oecd.org/education/school/44568106.pdf 
Öztürk, S. (2011). Müzik ögretmenliği programında alınan piyano egitiminin müzik ögretmeninin mesleki yasamina katkisı. Malatya: İnönü University Institute of Educational Scineces.

Seferoğlu, S. S. (2004). Öğretmen yeterlikleri ve mesleki gelişim. Bilim ve Aklın Aydınlı̆̆ında Eğitim, 58, 40-45.

Şeker, S. S. (2017). Müzik eğitimi bölümü öğretmen adaylarının akademik güdülenme ve akademik öz-yeterlik düzeylerinin incelenmesi. Abant İzzet Baysal Üniversitesi Eğitim Fakültesi Dergisi, 17(3), 1465-1484. https://doi.org/10.17240/aibuefd.2017.17.31178-338840

Şenol Sakin, A., \& Gürgan Öztürk, F. (2017). Reasons why music teachers prefer "recorder" or "melodica" as a classroom instrument. International Journal of Eurasia Social Sciences, 8(30), 1528-1546. Retrieved from http://www.ijoess.com/Makaleler/1672988202_14.\%201528-1546\%20ajda\%20\%c5\%9fenol\%20sakin.pdf

Shin, J. (2019). Becoming a music teacher: Korean music student teachers' perceptions of their student teaching experience. Music Education Research, 21(5), 549-559. https://doi.org/10.1080/14613808.2019.1673328

Sönmez, A. (2017). Kaynaştırma öğrencilerine uygulanan müzik ĕgitimine ilişsin müzik öğretmenlerinin görüşleri. Kırıkkale: Kırıkkale University.

Sungurtekin, Ş. (2016). Sinıf öğretmeni yetiştirme programında müzik eğitimi yeterliklerinin belirlenmesi ve sinıf ögretmeni adaylarının yeterliklerinin değerlendirilmesi (Unpublished doctoral dissertation). Ankara University, Ankara, Turkey.

Sušić, B. B. (2018). Preschool teachers' music competencies based on preschool education students' self-assessment. Croatian Journal of Education, 20(1), 113-129. https://doi.org/10.15516/cje.v20i0.3048

Talşık, E. (2016). Müzik Öğretmenlerinin Mesleki Genel Yeterlik Algıları ile Doyum ve Tükenmişlik Düzeyleri Arasındaki Bağıntının İncelenmesi. Mehmet Akif Ersoy University Education Faculty Journal, 37, 1-14. Retrieved from https://dergipark.org.tr/tr/pub/maeuefd/issue/19410/206439

Temiz, E. (2016). Pedagojik formasyon alan müzik öğretmeni adaylarının mesleki yeterlikleri. Journal of Turkish Studies, 11(3), 2165-2165. https://doi.org/10.7827/TurkishStudies.9139

Tepeköylü Öztürk, Ö., \& Soytürk, M. (2015). Beden Eğitimi, Müzik ve Resim/Görsel Sanatlar öğretmenlerinin iletişim becerilerinin incelenmesi. Journal of Kırsehir Educaiton Faculty, 16(3), 39-50. Retrieved from https://dergipark.org.tr/tr/download/article-file/1489209

Tunç, T., \& Bulut F. (2016). Müzik öğretmeni adaylarının müzik öğretimine yönelik özyeterlik inançlarının incelenmesi. Ĕgitim ve Öğretim Araştırmaları Dergisi, 5(3), 308-314.

Uçan, A. (2006). Müzik öğretmenliği yeterlikleri. Ulusal Müzik Eğitimi Sempozyumu Bildirisi, Denizli, 68-91.

Wilkerson, J. R., \& Lang, W. S. (2007). Assessing teacher competency: Five standards-based steps to valid measurement using the CAATS model. Thousand Oaks, CA: Corwin Press.

Yağcı, U., \& Aksoy, V. (2015). Müzik öğretmeni adaylarının akademik öz yeterlikleriyle öğretmenlik öz yeterlikleri arasındaki ilişkinin incelenmesi. Mehmet Akif Ersoy Üniversitesi Eğitim Fakültesi Dergisi, 33, 89-104. Retrieved from https://dergipark.org.tr/tr/pub/maeuefd/issue/19406/206329

Yokuş, T. (2014). Müzik öğretmeni adaylarının eğitme öğretme öz-yeterlikleri açısından değerlendirilmesi. Sanat Eğitimi Dergisi, 2(2), 43-56.

\section{Note}

Note 1. This study was presented as an oral presentation at the 26th EAS Conference organized under the theme of "Competences in Music Education" in Jelgava, Latvia.

\section{Copyrights}

Copyright for this article is retained by the author(s), with first publication rights granted to the journal.

This is an open-access article distributed under the terms and conditions of the Creative Commons Attribution license (http://creativecommons.org/licenses/by/4.0/). 